\author{
International Journal of Economics, Business and Accounting Research (IJEBAR) \\ Peer Reviewed - International Journal \\ Vol-4, Issue-2, 2020 (IJEBAR) \\ E-ISSN: 2614-1280 P-ISSN 2622-4771 \\ https://jurnal.stie-aas.ac.id/index.php/IJEBAR
}

\title{
HOW CUSTOMER SATISFACTION AND SWITCHING BARRIER AFFECT CUSTOMER LOYALTY OF PREPAID CARD USERS IN THE TELECOMMUNICATION SECTOR IN SAMARINDA
}

\author{
Fey Fey Tanzil1, Lorine Kalista Noor2 \\ Faculty of Economics and Business Mulawarman University 1,2 \\ E-mail:, chenvey1826@gmail.com,1k_noor@hotmail.com,
}

\begin{abstract}
The development of technology and the high of globalization, bring change to many people in the world. The rapid development of information technology has made telecommunication necessary. Communication service operators, such as the Mobile Telecommunication Sector that serves cellular telecommunications networks, always try to provide the best service so that people feel satisfied and become loyal to these communication services. This study aims to detect and analyze the effects of customer satisfaction and switching barrier on customer loyalty. Quantitative models are used in this study. Quoting sample used is Purposive Sampling with total of 100 customers of prepaid mobile telecommunication in Samarinda. The pattern of data accumulation is by questionnaire method and data analysis method by multiple linear regression analysis. To determine customer loyalty (customer loyalty) can be measured by variable of customer satisfaction and switching barriers.
\end{abstract}

Keywords: $\quad$ customer satisfaction, switching barrier, customer loyalty

\section{Introduction}

The development of technology and the high of globalization, bring change to people in the world. The rapid development of information technology has made telecommunications necessary. Communication service operators that supply mobile telecommunications networks are the choice for the public to communicate. Mobile telecommunications operators ultimately compete with each other to satisfy consumers and gain their loyalty. The development of communication technology is an object that is crucial and needed. Communication today no longer requires time and special place, at this point communication can be done anywhere.

This kind of communication causes the lack of meetings between people, they now rely on communication via mobile phone that easy to carry anywhere because of its handy form that can communicate anytime even when traveling. The use of mobile phones in this era has positive and negative impacts. The positive impact is we can communicate with family, friends, acquaintances, business relationships and anyone easily, while the negative impact is direct face-to-face social interaction begins to decrease.

Communication is the process of passing information and understanding from one person to another. Communication is a prerequisite for human life. Life will become empty if there is no communication interaction. To create expedite communication requires a number of sophisticated and up to date communication equipment. In this globalization, many products and types of mobile phones such as Android, iPhone, iPad, Tablet, Note and so on were created and provided high level of sophistication. Definitely, the mobile phone wants a provider or prepaid card that can support the quality of the product.

In Indonesia, there are 3 big providers that apply GSM-based technology, namely PT. Telekomunikasi Indonesia Seluler Tbk. (Telecommunications), PT. Indonesian Satellite Corporation Tbk. (Indosat), and PT. Excelcomindo Pratama Tbk. (Pro XL). New telecommunications service 


\author{
International Journal of Economics, Business and Accounting Research (IJEBAR) \\ Peer Reviewed - International Journal \\ Vol-4, Issue-2, 2020 (IJEBAR) \\ E-ISSN: 2614-1280 P-ISSN 2622-4771 \\ https://jurnal.stie-aas.ac.id/index.php/IJEBAR
}

companies, both GSM and CDMA-based, emerged, followed by Hutchison CPT (Three), Axis (Axis), PT. Telkom Indonesia (Telkom Flexi), Mobile-8 (Fren), PT. Smart Telecom (Smart). This triggers competition between providers or prepaid cards which makes producers try to win this competition. The Telecommunications sector is the largest cellular telecommunications mechanic in Indonesia.

In running business in the telecommunication sector that provides mobile telecommunications services, the type of GSM (Global System for Mobile) is a type of mobile operator that is already global throughout the world. On the official website of the Telecommunications Sector (www.Bidang Telekomunikasi.com), the Telecommunications company publicizes that the number of consumers has reached 131.5 million customers throughout Indonesia. That number increased from 125 million consumers at the end of 2012. The Telecommunications sector recorded 10.4 percent revenue from year to year, which was supported by broadband data progress, while EBITDA and net income grew by 11.1 percent and 11.9 percent year-on-year. to year. The telecommunications sector should not be complacent about this achievement, because competitors are also increasingly aggressively attracting the attention of the public to become its customers. With the current conditions in the telecommunications sector, there are problems both from within and outside.

Product quality which is a problem is a network problem, because Telecommunications products have wide networks throughout Indonesia and as a result there are often obstacles in several networks in various places. As for prices, the Telecommunications Sector is leading to higher telephone / text messages rates compared to other operators. The increasingly fierce competition between these product supply companies is one of the reasons for tough companies to increase the number of customers. Abundant products in various markets with a variety of advantages and facilities provided by competitors in the telecommunications world, so it is tough for new companies in seizing market share of competitors. In addition, to enter a new market, a sizable capital is needed. Doing a variety of power to maintain existing markets, one of which is through a way that is to provide satisfaction for consumers.

According to Oliver (1999) in Liu, et al. (2011) loyalty has been interpreted as "a commitment held by consumers to repurchase or re-subscribe to selected products or services that they have used consistently in the future". It is the result of customer satisfaction, positive customer experiences, and the overall value of the goods or services a customer receives from a business and services that have been used in Flash Telecommunications products, also closely related to the factors that shape it, one of which is the switching barrier created by a product. In the same journal Liu, et al. (2011) said that asking for what was done was Pull-in and Push-back. Decision of attraction related to the quality of the relationship (satisfaction and trust). Customer satisfaction is the most important thing for customers who are satisfied, happy and ultimately have no reason to leave. The push-back approach is carried out by discussing switching barriers. Companies will have a lot to achieve customer loyalty from customers with increasingly crowded competition between companies in the Telecommunications Field. Based on the description and explanation above, the authors propose the title "Analysis of the Effect of Customer Satisfaction and Switching Barriers on Customer Loyalty of Prepaid Card Users in the Telecommunications Sector in Samarinda".

\title{
2. Literature Review
}

\subsection{Customer Satisfaction}

Satisfaction comes from Latin which means "efforts to meet needs" (Tjiptono, 2005: 349). Generally the expectations of customers are predictions of something that will be received when they have bought or consumed a product. Perceived performance is the customer's absorption of what he receives after consuming the product he bought. Kotler (2005:70) defines customer satisfaction as a 'person's feeling of pleasure or disappointment, which resulted from comparing a product's perceived performance or 


\author{
International Journal of Economics, Business and Accounting Research (IJEBAR) \\ Peer Reviewed - International Journal \\ Vol-4, Issue-2, 2020 (IJEBAR) \\ E-ISSN: 2614-1280 P-ISSN 2622-4771 \\ https://jurnal.stie-aas.ac.id/index.php/IJEBAR
}

outcome against his/her expectations'. Umar (2008: 14) defines satisfaction as a response to fulfillment from customers. Satisfaction is the result of evaluating that the product or service used meets expectations. Customers who are satisfied are customers who will surely share satisfaction with service providers, therefore customers and service providers will be equally given an advantage.

\title{
2.2 Switching Barriers
}

Nowadays, there are many marketing researches that pay attention to the influence of switching barriers that refer to any factor that makes it difficult for consumers to switch service providers or companies. According to Jones, et al. (2000 switching barriers are factors that make it difficult for customers to switch service providers. This constraint is not only based on the estimated economic values, but also relates to psychological, social, functional and ritual values (Kotler, 2007: 117). The three types of switching costs include:

a. Transaction Cost

The amount of money spent by a customer when switching service providers as a remuneration.

b. Learning Cost

c. Learning is seen as a process where experience causes changes in knowledge, attitudes and or behavior. When consumers switch from service providers, consumers must adjust themselves again to new service providers.

d. Artificial Cost,

Costs are sourced from the company itself to retain its customers. The company provides complementary services tailored to customer needs.

\subsection{Customer Loyalty}

Loyalty can also be seen as a commitment to repurchase products / services that are preferred in the future (Liu et al, 2010). This definition is consistent with what was expressed by Tjiptono (2012: 482), namely customer loyalty is a customer's commitment to a brand, based on a very positive attitude and reflected in consistent repurchases. Meanwhile, customer loyalty in the context of service marketing, Tjiptono (2012: 428) as a response is closely related to pledges to uphold commitments that underlie relationship sustainability, and are usually reflected in ongoing purchases from the same service provider for basic dedication and pragmatic constraints.

A customer can be said to be loyal to the company if a particular customer makes a purchase marked by an interval of time based on a series of decisions. Loyalty is characterized by a condition that shows how long to use the product accompanied by a purchase action that is more than twice. Griffin (2010: 4) added that a consumer can be said to be loyal when the consumer shows the activity of buying regularly or there is a condition where it requires the consumer to buy at least twice in a certain time interval.

\section{Attributes of customer loyalty}

According to (Griffin, 2010: 31) there are 4 attributes of loyalty, namely:

a. Makes regular repeat purchase, making repeated purchases within a certain period.

b. Purchase across product and service line, Loyal customers not only buy one type of product, but also buy other products and services at the same business entity.

c. Refers other, recommend experience about products and services to colleagues or other customers so as not to buy products and services from other business entities. 
International Journal of Economics, Business and Accounting Research (IJEBAR)

Peer Reviewed - International Journal

Vol-4, Issue-2, 2020 (IJEBAR)

E-ISSN: 2614-1280 P-ISSN 2622-4771

https://jurnal.stie-aas.ac.id/index.php/IJEBAR

\section{Research Methods}

\subsection{Conceptual Framework}

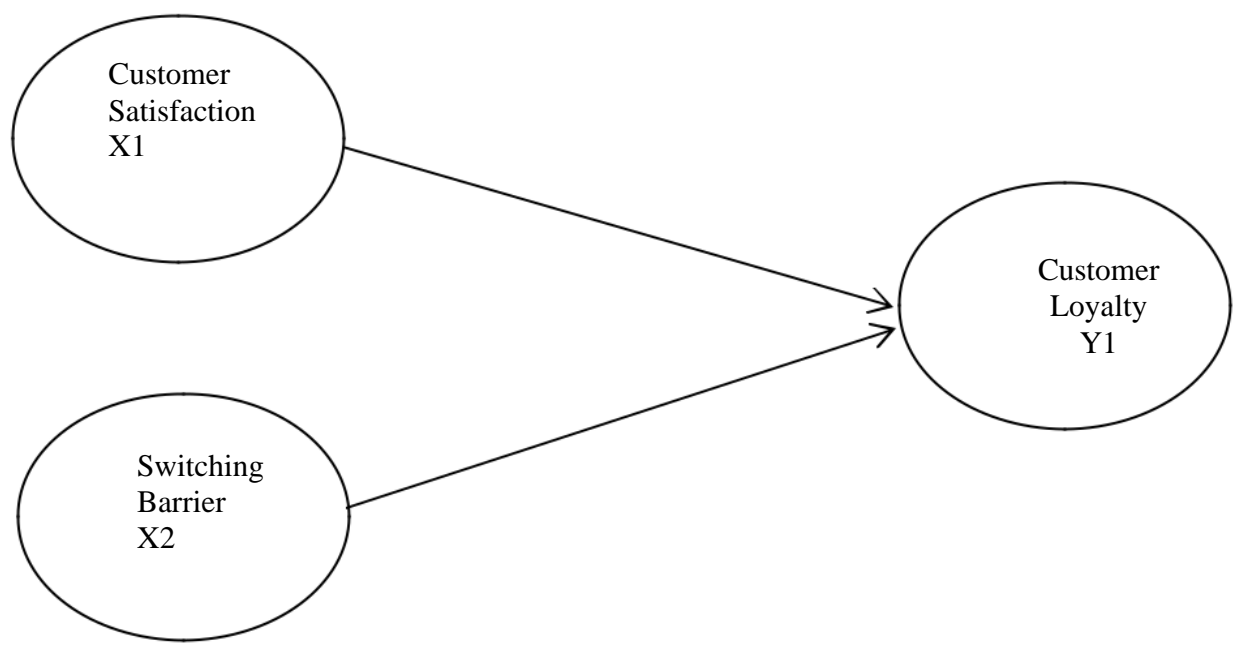

Figure 1. Conceptual Model

\subsection{Hypotheses}

Hypothesis is a temporary statement or the most probable allegation that still needs to be sought (Sugiyono, 2012: 93). Based on the concepts and results of the empirical study, the researchers propose several hypotheses in this study as follows:

H1: There is a significant effect between Customer Satisfaction on Customer Loyalty.

$\mathrm{H} 2$ : There is a significant effect between Switching Barriers on Customer Loyalty.

\subsection{Population and Sample}

Population is a "generalization area consisting of objects or subjects that have certain qualities and characteristics determined by researchers to be studied and concluded" (Sugiyono, 2010: 115). In this study, the population used by researchers was all consumers or customers of prepaid telecommunications cards in Samarinda.

The sample of this study was customers in the area of Mulawarman University (students) who used prepaid telecommunication cards in the past year. The sampling technique used is convenience sampling, which means the researcher uses the subjects that are nearest and available to participate in the research study. The number of samples was determined by 100 respondents then the Slovin formula calculation was used.

\subsection{Data Types and Sources}

\subsubsection{Types of Data}

a. Qualitative Data, it is collected using questionnaires, interviews, or observation, and frequently appears in narrative form.

b. Quantitative data, its data that can either be counted or compared on a numeric scale often used by researcher to quantify a problem. 
International Journal of Economics, Business and Accounting Research (IJEBAR)

Peer Reviewed - International Journal

Vol-4, Issue-2, 2020 (IJEBAR)

E-ISSN: 2614-1280 P-ISSN 2622-4771

https://jurnal.stie-aas.ac.id/index.php/IJEBAR

\subsubsection{Sources of Data}

a. Primary Data, Primary data is data that is collected by a researcher from first-hand sources, using methods like surveys or interviews. In this study, primary data includes data from the distribution of questionnaires to respondents.

b. Secondary Data, Secondary data is data collected from studies, surveys, or experiments that have been run by other people or for other research.

\subsection{Data Analysis}

\section{Result of Simple Linear Regression \\ Regression}

Descriptive Statistics

\begin{tabular}{|l|r|r|r|}
\hline & Mean & Std. Deviation & N \\
\hline Customer Loyalty & 7.0857 & 2.04898 & 100 \\
Customer Satisfaction & 5.7714 & 2.10162 & 100 \\
Switching Barier & 4.1714 & 1.94763 & 100 \\
\hline
\end{tabular}

In the Descriptive Statistics table shows that the mean of Customer Loyalty (Y1) with the number of respondents 100 is 7.0857 with a standard deviation of 2.04898 , the mean of customer satisfaction is 5.7714 with a standard deviation of 2.10162 , and switching barriers with the mean of 4.1714 the standard deviation is 1,94763 .

\section{Correlations}

\begin{tabular}{|c|c|c|c|c|}
\hline & & $\begin{array}{l}\text { Customer } \\
\text { Loyalty }\end{array}$ & $\begin{array}{c}\text { Customer } \\
\text { Satisfaction }\end{array}$ & $\begin{array}{l}\text { Switching } \\
\text { Barier }\end{array}$ \\
\hline \multirow[t]{3}{*}{ Pearson Correlation } & $\begin{array}{l}\text { Customer } \\
\text { Loyalty }\end{array}$ & 1.000 & .779 & .726 \\
\hline & $\begin{array}{l}\text { Customer } \\
\text { Satisfaction }\end{array}$ & .779 & 1.000 & .913 \\
\hline & Switching Barier & .726 & .913 & 1.000 \\
\hline \multirow[t]{4}{*}{ Sig. (1-tailed) } & Customer & & .000 & .000 \\
\hline & Loyalty & & & 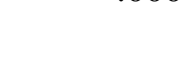 \\
\hline & Satisfaction & .000 & & .000 \\
\hline & Switching Barier & .000 & .000 & \\
\hline \multirow[t]{3}{*}{$\mathrm{N}$} & $\begin{array}{l}\text { Customer } \\
\text { Loyalty }\end{array}$ & 35 & 35 & 35 \\
\hline & $\begin{array}{l}\text { Customer } \\
\text { Satisfaction }\end{array}$ & 35 & 35 & 35 \\
\hline & Switching Barier & 35 & 35 & 35 \\
\hline
\end{tabular}

In the correlations table, the correlation or relationship between the three variables is a positive variable, customer satisfaction with customer loyalty obtained $r=0.779$ with probability $=0.000<0.05$ 


\section{Coefficientsa}

International Journal of Economics, Business and Accounting Research (IJEBAR)

Peer Reviewed - International Journal

Vol-4, Issue-2, 2020 (IJEBAR)

E-ISSN: 2614-1280 P-ISSN 2622-4771

https://jurnal.stie-aas.ac.id/index.php/IJEBAR

then Ho is rejected, which means that there is a significant correlation between customer satisfaction scores and customer loyalty. Variable frequency of switching barriers with customer loyalty is $r=0.726$

\section{Variables Entered/Removed}

\begin{tabular}{|l|l|l|l|}
\hline Model & \multicolumn{1}{|l|}{ Variables Entered } & $\begin{array}{c}\text { Variables } \\
\text { Removed }\end{array}$ & Method \\
\hline 1 & $\begin{array}{l}\text { Switching barier, } \\
\text { customer satisfacionb }\end{array}$ & & Enter \\
\hline
\end{tabular}

a. Dependent Variable: KINERJA

b. All requested variables entered.

This Variable Entered / Removed table explains the variables that are entered or discarded and the methods used. In this case the variables included are customer satisfaction and switching variables as predictors and the enter method is used.

\section{Model Summaryb}

\begin{tabular}{|c|c|c|c|c|c|c|c|c|c|}
\hline \multirow[b]{2}{*}{$\begin{array}{l}\text { Mod } \\
\text { el }\end{array}$} & \multirow[b]{2}{*}{$\mathrm{R}$} & \multirow[b]{2}{*}{$\begin{array}{c}\mathrm{R} \\
\text { Square }\end{array}$} & \multirow[b]{2}{*}{$\begin{array}{l}\text { Adjusted } \\
\text { R Square }\end{array}$} & \multirow{2}{*}{$\begin{array}{l}\text { Std. Error } \\
\text { of the } \\
\text { Estimate }\end{array}$} & \multicolumn{5}{|c|}{ Change Statistics } \\
\hline & & & & & $\begin{array}{l}\text { R Square } \\
\text { Change }\end{array}$ & $\begin{array}{c}\mathrm{F} \\
\text { Change }\end{array}$ & df1 & df2 & $\begin{array}{l}\text { Sig. F } \\
\text { Change }\end{array}$ \\
\hline 1 & $.780_{\mathrm{a}}$ & .608 & .583 & 1.25741 & .608 & 24.786 & 2 & 32 & .000 \\
\hline
\end{tabular}

a. Predictors: (Constant), customer satisfaction dan switching barier

b. Dependent Variable: Customer loyalty

In this table explain the R-square of 0.608 or $60.8 \%$ which shows that the regression model can explain the data of $60.8 \%$ and the rest is influenced by other variables or in other words the customer satisfaction variable can be explained by the switching barrier variable of $60.8 \%$ the remaining $39.2 \%$. The standard error of estimate in this table is 1.25741 on the customer loyalty variable. In the previous analysis the standard deviation of descriptive statistics was 1.94763 where the standard deviation rate was far greater than the standard error estimate of only 1.25741

ANOVAa

\begin{tabular}{|ll|r|r|r|r|r|}
\hline \multicolumn{2}{|l|}{ Model } & \multicolumn{1}{|c|}{$\begin{array}{c}\text { Sum of } \\
\text { Squares }\end{array}$} & Df & Mean Square & F & Sig. \\
\hline 1 & Regression & 78.377 & 2 & 39.188 & 24.786 & $.000 \mathrm{~b}$ \\
& Residual & 50.595 & 32 & 1.581 & & \\
& Total & 128.971 & 34 & & & \\
\hline
\end{tabular}

a. Dependent Variable: CUSTOMER LOYALTY

b. Predictors: (Constant), CUSTOMER SATISFACTION, SWITHING BARIER

In this table, there is a significant effect on customer satisfaction (X1) and the variable switching barrier (X2) simultaneously on customer loyalty (Y). F value (f arithmetic) is 24.786 and (significant level) sig $=0,000$ 
International Journal of Economics, Business and Accounting Research (IJEBAR)

Peer Reviewed - International Journal

Vol-4, Issue-2, 2020 (IJEBAR)

E-ISSN: 2614-1280 P-ISSN 2622-4771

https://jurnal.stie-aas.ac.id/index.php/IJEBAR

\begin{tabular}{|c|c|c|c|c|c|c|c|c|c|c|}
\hline \multirow[b]{2}{*}{ Model } & \multicolumn{2}{|c|}{$\begin{array}{c}\text { Unstandardized } \\
\text { Coefficients }\end{array}$} & \multirow{2}{*}{$\begin{array}{c}\begin{array}{c}\text { Standardiz } \\
\text { ed } \\
\text { Coefficien } \\
\text { ts }\end{array} \\
\text { Beta }\end{array}$} & \multirow[b]{2}{*}{$\mathrm{T}$} & \multirow[b]{2}{*}{ Sig. } & \multicolumn{3}{|c|}{ Correlations } & \multicolumn{2}{|c|}{$\begin{array}{c}\text { Collinearity } \\
\text { Statistics }\end{array}$} \\
\hline & $\mathrm{B}$ & $\begin{array}{l}\text { Std. } \\
\text { Error }\end{array}$ & & & & $\begin{array}{l}\text { Zero- } \\
\text { order }\end{array}$ & Partial & Part & $\begin{array}{c}\text { Toleran } \\
\text { ce }\end{array}$ & VIF \\
\hline $1 \quad$ (Constant) & -.159 & .805 & & -.197 & .845 & & & & & \\
\hline $\begin{array}{l}\text { CUSTOMER } \\
\text { SATISFACTIO } \\
\mathrm{N}\end{array}$ & .646 & .252 & .697 & 2.568 & .015 & .779 & .413 & .284 & .166 & 6.015 \\
\hline $\begin{array}{l}\text { SWITCHING } \\
\text { BARIER }\end{array}$ & .085 & .258 & .089 & .328 & .745 & .726 & .058 & .036 & .166 & 6.015 \\
\hline
\end{tabular}

a. Dependent Variable: CUSTOMER LOYALTY

In the coefficient table in column B in constants -159 , compensation is 646 and motivation is 0.085 .

Based on the data above, it can be said that: a constant of -159 and a regression coefficient of X1 0.085 and a coefficient X2 of 0.085 . Customer Satisfaction has a positif and significant on Customer Loyalty with t-statistic 2, $568>1,96$. Switching Barrier has a positif but not significant effect on Customer Loyalty with t-statistics $0,328<1,96$.

\section{Conclusion and suggestion}

\section{Conclusion}

Based on the previous studies, several conclusions can be drawn which can be used to answer the problems that have been formulated in this study. Following are some conclusions from this research:

a. Customer satisfaction has a positive and significant effect on Customer loyalty

b. Barrier switching has a positive but not significant effect on Customer loyalty

\section{Suggestion}

From the conclusions obtained, the authors provide suggestions for the company:

a. The company must maintain customer satisfaction because it has been good for the company

b. Factors that make it difficult for customers to switch to other product or service providers are still in the sufficient category. So, the researcher advice to telecommunications companies in order to provide prices based on specifications to consumers. These suggestions are a number of factors that make it difficult for customers to switch to other product or service providers.

\section{References}

Hong, I.B. \& Cho, H. 2011. The Impact of Consumer Trust on Attitudinal Loyalty and Purchase Intention in B2C E-marketplace: Intermediary Trust vs Seller Trust. International Journal of Information Management, 31(2011):469-479.

Kotler, Philip. 2007. Manajemen Pemasaran, Analisis Perencanaan, Pengendalian, Prentice Hall, Edisi Bahasa Indonesia, Jakarta: Salemba Empat.

Kim. et, al., 2004. The effects of customer satisfaction and switching barrier on customer loyalty in

Korean mobile telecommunication services. Elsevier Business and Management, pp. 145159

Liu. et. al., 2010. An Empirical Study on The E-Service Quality on Online Customer Satisfaction and

Loyalty. Nankai Business Review International, Vol. 1. pp. 273-283

Profile : Bidang Telekomunikasi corporate. (2012, Agustus). Diakses 25 Maret, 2018, 
International Journal of Economics, Business and Accounting Research (IJEBAR)

Peer Reviewed - International Journal

Vol-4, Issue-2, 2020 (IJEBAR)

E-ISSN: 2614-1280 P-ISSN 2622-4771

https://jurnal.stie-aas.ac.id/index.php/IJEBAR

dari Bidang Telekomunikasi.com:http://www. Bidang

Telekomunikasi.com/about/corporate/368-Profile.html

Sugiyono. 2010. Metode Penelitian Kuantitatif Kualitatif \& RND. Bandung: Alfabeta

Telkom:Laporan Tahunan 2011. (2012). Diunduh 11 September 2012, dari Telkom. co.id : http://www.telkom.co.id/UHI/UHI2011/ID/pdf/Telkom_LT2011.pdf

Telkom:AnnualReport 2011. (2012). Diunduh 21 September 2012, dari Telkom.co.id: "http://www.Bidang

Telekomunikasi.com/media/upload/annualreport/AR_Bidang

Telekomunikasi_2011_ENG_rev.\%2021Sept2012_Web\%20Version.pdf"

Tjiptono, Fandy. 2005. Service Quality and Satisfaction. Andi Offset. Yogyakarta.

Tjiptono, F. 2012. Strategi pemasaran. Malang: Bayu media Publishing 